
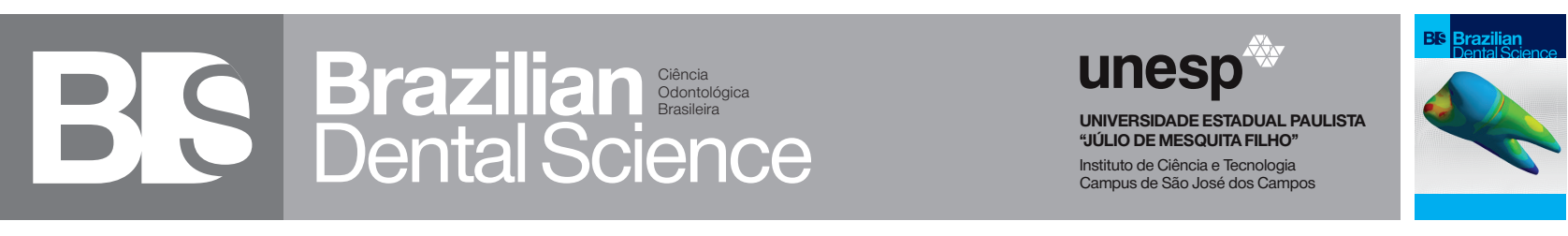

\title{
Bone grafting and osseointegration in the area of maxillary tooth agenesis. Case report
}

\author{
Incorporação de enxertos ósseos e osseointegração em área de agenesia dentária maxilar. Caso clínico
}

Rodrigo Dias NASCIMENTO' ${ }^{1}$, Paula Elaine CARDOSO ${ }^{2}$, Fabio da Silva MATUDA ${ }^{3}$, Fernando Vagner RALDI ${ }^{1}$, Michelle Bianchi de MORAES ${ }^{1}$

1 - São Paulo State University (Unesp) - Institute of Science and Technology - São José dos Campos - Department of Diagnosis and Surgery - SP - Brazil.

2 - São Paulo State University (Unesp) - Institute of Science and Technology - São José dos Campos -Department of Restorative Dentistry - SP - Brazil.

3 - Periodontics - University of Vale do Paraíba (Univap) - São José dos Campos - SP - Brazil.

\begin{abstract}
The high dental implant success rate is directly linked to the presence of adequate bone volume, which enables and maintains the osseointegration of dental implants. This study aimed to report a clinical case of a female with agenesis of the right maxillary lateral incisor (12), due to cleft lip and palate. Because the bone and mucosal defects of the area, the treatment planning comprised guided bone regeneration with the association of autogenous bone, platelet rich plasm (PRP), and expanded polytetrafluoroethylene membrane (e-PTFE,Gore-Tex), performed in 2005. After nine months, a new evaluation was carried out and revealed that the area was still not suitable for implant placement. Thus, an allogenous bone graft was planned. Elapsed another nine months, the implant was placed. After six months, the implant was reopened and a metal-ceramic crown was installed. The 5-year following-up appointment showed the presence of fistula with purulent secretion at the buccal cortical plate. We attempted to control the fistula with antibiotics and follow-up clinically and radiographically. The examinations suggested a communication with the right nasal cavity, which decreased until nowadays. The osseointegrated dental implant was in function, without symptomatology. The autogenous bone graft is still more effective than allogenous bone graft. Further studies are necessary to achieve better evaluations.
\end{abstract}

\section{KEYWORDS}

Bone graft; Dental implant; Osseointegration.

\section{RESUMO}

A realização de elevadas taxas de sucesso em implantodontia está diretamente ligada à presença de volume de tecido ósseo adequado, que permiti e mantém a osseointegração dos implantes dentários. O objetivo deste trabalho foi apresentar o caso clínico da paciente, com agenesia do dente 12 , decorrente da fissura lábio-palatina. Devido ao defeito ósseo e mucoso na região, foi planejada a realização da técnica de regeneração óssea guiada, associando a utilização de osso autógeno, plasma rico em plaquetas (PRP) e membrana de politetrafluoretileno expandido (PTFE-e, Gore-Tex) realizado em 2005. Após 9 meses, nova avaliação foi realizada, porém a área estava inadequada para o posicionamento do implante, optou-se por um novo enxerto, agora alógeno. E após mais 9 meses foi instalado o implante. Aguardou-se 6 meses até a reabertura, para o implante entrar em função por meio de uma coroa metalocerâmica. Passados 5 anos de controle a paciente apresentou uma fístula com secreção purulenta na parede óssea vestibular, controlada com terapia medicamentosa, e após alguns anos, pelo exame clínico e tomográfico, sugeriu-se comunicação com a cavidade nasal direita, porém regrediu e está sendo preservada até os dias atuais, com o implante osseointegrado em função, sem sintomatologia. O enxerto ósseo autógeno ainda é superior em relação ao alógeno. Outros estudos são necessários para melhores avaliações.

\section{PALAVRAS-CHAVE}

Enxerto ósseo; Implante dentário; Osseointegração. 


\section{INTRODUCTION}

$\mathrm{T}$ he high dental implant success rate is directly linked to the presence of adequate bone volume, which enables and maintains the osseointegration of dental implants $[1,2]$. Notwithstanding, many factors (e.g.: tooth loss, trauma, and periodontitis) decrease the amount of available bone [3]. In the absence of adequate bone volume, one of the most predictable treatments to restore the bone morphology and enable oral rehabilitation is bone grafting [4].

Autogenous bone graft is the gold standard procedure for bone augmentation for the maxillary and mandibular bone [5,6]. However, this technique is also associated with the presence of the donor area and problems, as post-operative pain, risk of paresthesia, limitation in the quality and quantity of the available bone, which may require the use of other bone substitute [7]. Accordingly, alternative treatment approaches employing xenogeneic and allogeneic bone may restore the lost bone morphology, maintain the bone structure, or increase the amount of bone tissue [8].

The allogenous graft is increasingly gained attention [9] due to the strict processing guidelines, thus eliminating the risk of cross-contamination, and because of the osteoconductive property [10]. On the other hand, the xenogeneic grafts draw attention in oral surgery because they are completely absorbable and are becoming the basis for the guided bone regeneration [11].

The clinical impact of the xenogeneic and allogeneic over autogenous bone grafting on the long-term clinical performance of in function oral implants is still controversial, either about survival or biological complications [8].

This study aimed to report a clinical case using bone grafts and dental implant to treat the anterior maxillary tooth agenesis with 10 years of following-up.

\section{CLINICAL CASE}

\section{Surgical Procedures and Prosthetic Rehabilitation}

A female patient, aged 30 years, ASA 2, was referred for osseo integrated implant for treating tooth agenesis of the maxillary lateral incisor (\#12). The agenesis was caused by cleft lip and palate repaired at childhood. The patient had already been submitted to orthodontic treatment.

The clinical examination revealed lack of both bone and mucosal tissue due to the congenital cleft lip and palate. The tomography confirmed the local bone deficiency that required regenerative procedure prior to the implant placement (Figure 1).

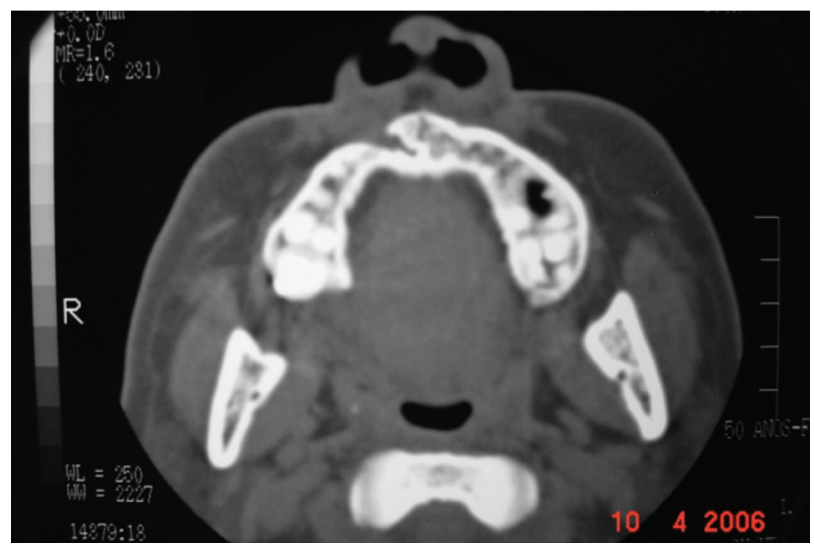

Figure 1 - Tomography - axial cut

Because of the defect characteristics, in 2005, we planned to perform bone grafting through guided bone regeneration with autogenous bone, platelet rich plasma (PRP), and expanded polytetrafluoroethylene membrane (e-PTFE Gore-Tex). After extra and intraoral asepsis respectively with $2 \%$ and $0,12 \%$ chlorhexidine digluconate, and all the procedures to prevent contamination, local anesthesia was performed ( $2 \%$ mepivacaine and 1/100,000 epinephrine). 
Next, the mucoperiosteal flap was raised to expose the bone defect in the edentulous area of the maxillary lateral incisor (12). Then, the autologous bone graft was collected from the chin (Figure 2 and 3). Following, the particulate bone was associated with platelet rich plasm (PRP), (Figure 4). An absorbable membrane of bovine cortical bone (Genderm - Baumer) was two-folded and stabilized at the palatal surface. The graft material was placed on the bone defect and the de e-PTFE membrane (Gore-Tex) was stabilized at the buccal surface through thumbtacks. After 9 months, a new tomography revealed the closure of the alveolar ridge cleft, but the bone had inadequate condition for the ideal three-dimensional positioning of the implant during placement.

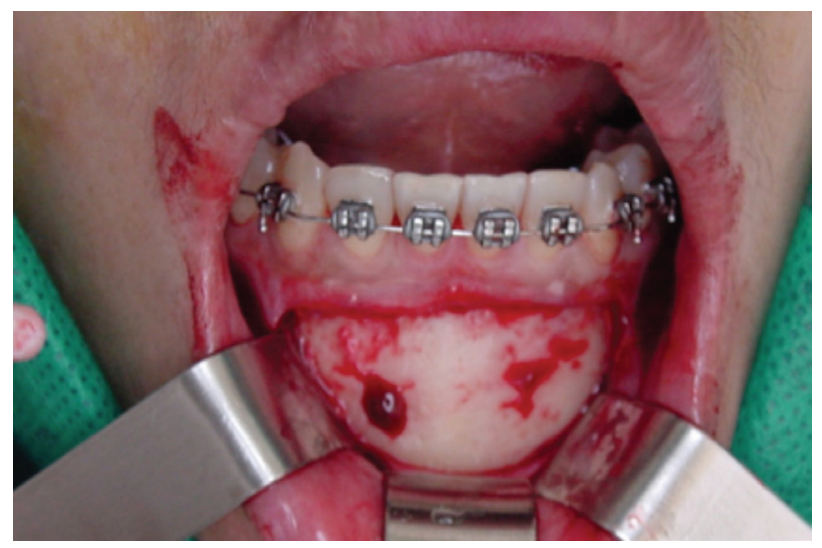

Figure 2 - Donor site access

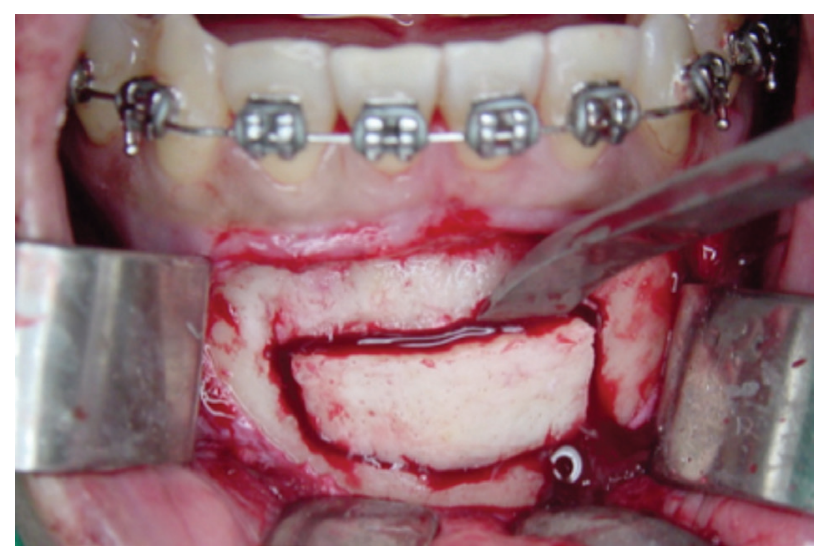

Figure 3 - Autologous bone grafting

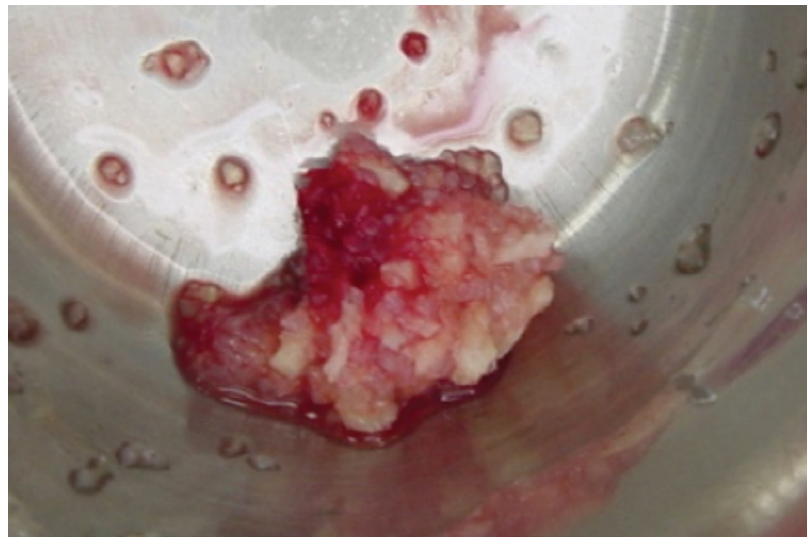

Figure 4 - Particulate autologous bone with PRP

At that moment, attempting to decrease the procedure morbidity, considering the impossibility of another bone removal from the chin, and meeting the patient's desire, we opted to use allogeneic cortical-cancellous bone grafting donated by a skeletal-muscle tissue bank (Unioss ${ }^{\circledR}$ - Marília, SP-Brazil). The block was fixed through of screw, and small perforations were executed on the cortical bone surface of the in-block bone graft, far from the grafting area, to achieve revascularization and favor the graft incorporation (Figure 5).

Elapsed more nine months, another tomography showed good conditions for osseointegration. After waxing and the construction of a surgical template, the implant (Titamax CM 3,5x11 - Neodent $\AA$, Curitiba, Brazil) was placed with torque of $45 \mathrm{~N} / \mathrm{cm}$ (Figure 6).

After more six months, the implant was reopened and the osseointegration was checked. Then a metal-ceramic crown was installed (Figure 7). The patient was instructed regarding oral hygiene and need of regular following-up. 


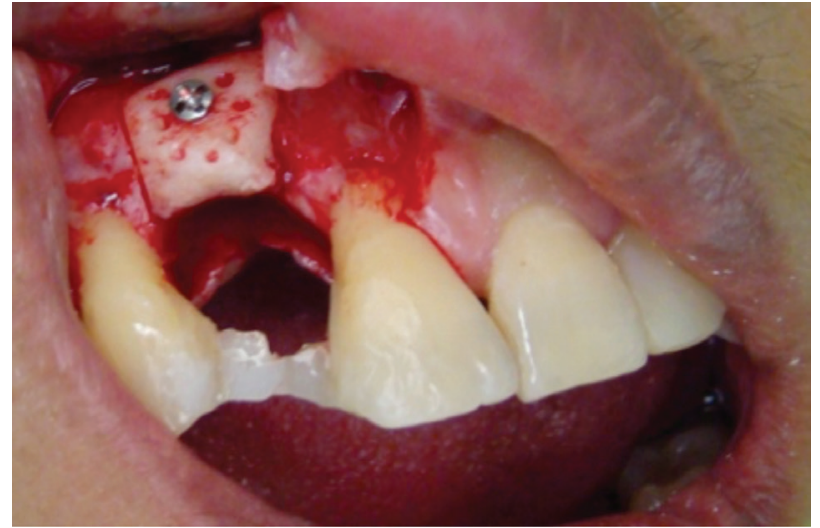

Figure 5 - Allogenous bone grafting in place

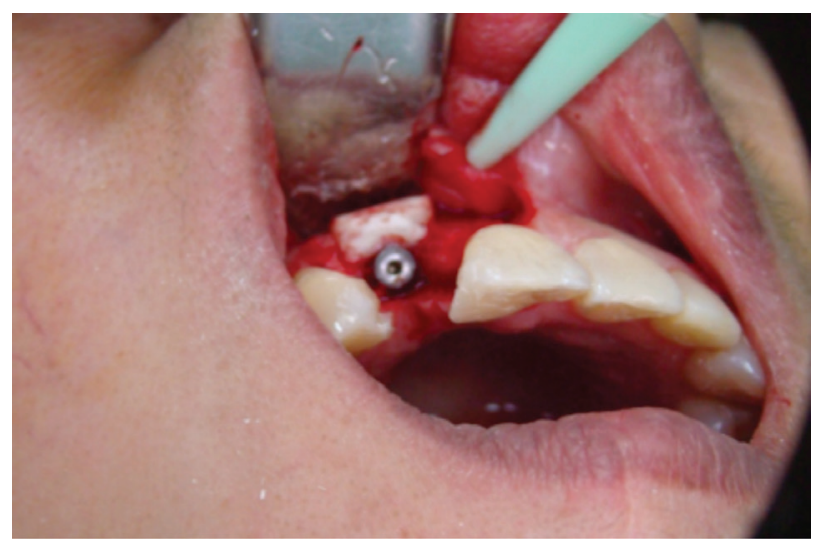

Figure 6 - Implant placement with $45 \mathrm{~N}$ torque

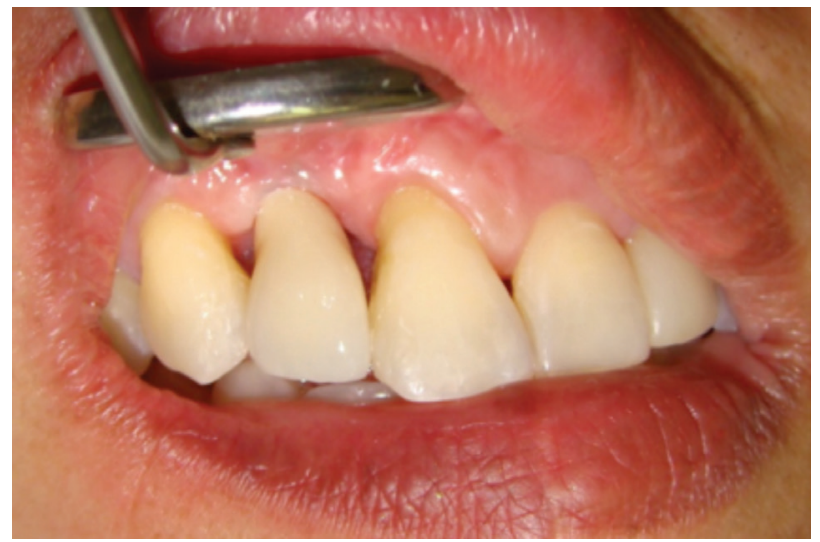

Figure 7 - Metal-ceramic implant-supported prosthesis
At the 5-year following-up appointment, a fistula with purulent secretion was diagnosis on the buccal bone surface of the implant. The treatment comprised antibiotics (Amoxicillin 500mg associated with Metronidazole 400mg) and mouth rinsing (Periogard $(\mathrm{R})$. After 20 days, the lesion disappeared and the patient was followed-up.

At 10-year following-up appointment, the clinical and tomography examination revealed the presence of the fistula, with discreet nasal secretion, suggesting the communication with the nose. This communication was treated and the patient remained asymptomatic.

\section{DISCUSSION}

To the best of the author's knowledge, the literature claims no difference between particulate and in-block autologous bone grafting regarding the biological aspect, except for the obvious size difference. [12].The advantages of the use of the particulate bone are: the histological partial resorption of the biomaterial, enabling that the natural hydroxyapatite is kept totally inside the bone cavity and mechanical hemostasis [12]. Accordingly, an in vitro study on particulate autogenous and xenogenous bone grafts demonstrated that the autogenous bone proliferation is faster than the cell growth of the xenogeneic bone graft [13]. This justifies the use of the particulate bone and the favorable outcome of the osseointegration implant in this case report.

After the six-month histomorphometric evaluation between in-block allogeneic and autogenous bone graft, limited amount (8\%) of viable allogeneic bone were found, consisting of conjunctive tissue and non-vital bone; while autogenous blocks showed approximately three times more vital bone (28\%)[14,15]. Recently, other histomorphometric analysis $[15,16]$ agreed with previous results evidencing the best integration and remodeling of the autogenous bone over other allogeneic bone types. 
The literature affirms that the allogeneic cancellous-cortical bone undergoes more resorption over time than do the allogeneic cortical bone [10]. The rationale behind this fact is that the cancellous bone surface is higher than that of the cortical bone at the same bone volume, and the number of cells surviving in the cancellous bone is also higher than that of the cortical bone $[15,16]$.

The bone remodeling after allogeneic graft occurs by means of newly-formed bone and blood vessels spread through the grafted material [14]. This regenerative and remodeling process of in-block grafts is influenced by many factors, as allogeneic bone origin, surgical technique, bone volume available before the surgery, healing time, and different receptor sites [17]. These are important points to be considered during the patients' evaluations.

Differently from previous studies [15,16], a new histological and histomorphometric evaluation of autogenous bone graft [14], between three and nine months, indicate signs of active remodeling. However, the grafted bone had substantial amounts of non-vital bone and little neovascularization, regardless of the time. The authors suggested that most part of the osteocytes of the monocortical bone did not survive the grafting and the neovascularization, which explained by the slow remodeling [14].

On the other hand, another histological analysis of the autogenous bone showed an advanced stage of bone remodeling with sparse newly-formed bone, while the allogenous graft showed large amounts of necrotic bone surrounded by low remodeling rate [13]. In another study on animal and human model, the allogeneic bone showed inadequate revascularization, decrease of the mineral deposition, while the autogeneic bone revealed small differences between the residual and grafted bone [16]. An in vivo study with autogenous and allogenous bone showed signs of delayed remodeling of the latter, seven months after the grafting, with small amounts of remodeling bone [15] All this aforementioned discussion on the outcomes of allogeneic grafts may explain the presence of the bone fistula, at the allogeneic graft area, in this case report $[16,17]$.

Despite of this drawback, the allogenous graft has the advantages of little morbidity, shorter surgical time and trauma for the patient, unlimited offer of graft material, and little blood loss, which justified the option for the second grafting in this case report [14].

\section{CONCLUSION}

Although it had inadequate condition for the ideal three-dimensional positioning of the implant in the first bone grafting performed, due to presence of bone fistula and nasal secretion after implant placement in the area of the second bone grafting performed and also based on the literature research, the 10-year following-up revealed that autogenous bone graft was better than the allogenous bone graft in this clinical case report. Further studies are necessary for better evaluations.

\section{REFERENCES}

1. Akagawa $Y$, Wadamoto M, Sato $Y$, Tsuru $H$. The three- dimensional bone interface of an osseointegrated implant: a method for study. J Prosthet Dent. 1992 Nov;68(5):813-6.

2. Wadamoto M, Akagawa $Y$, Sato $Y$, Kubo T. The three- dimensional bone interface of an osseointegrated implant. I: A morphometric evaluation in initial healing. J Prosthet Dent. 1996 Aug;76(2):170-5.

3. Barber HD, Betts NJ. Rehabilitation of maxillofacial trauma patients with dental implants. Implant Dent. 1993 Fall;2(3):191-3.

4. Chiapasco, M, Zaniboni M, Boisco M. Augmentation procedures for the rehabilitation of deficient edentulous ridges with oral implants. Clin Oral Implants Res. 2006 0ct;17 Suppl 2:136-59.

5. Misch CM, Misch CE. The repair of localized severe ridge defects for implant placement using mandibular bone grafts. Implant Dent. 1995 Winter;4(4):261-7.

6. Nowzari H, Aalam AA. Mandibular cortical bone graft part 2 surgical technique, applications, and morbidity. Compend Contin Educ Dent. 2007 May;28(5):274-80; quiz 281-2.

7. Zerbo IR, Lange GL, Joldersma M, Bronckers AL, Burger EH. Fate of monocortical bone blocks grafted in the human maxilla: a histological and histomorphometric study. Clin Oral Implants Res. 2003 Dec;14(6):759-66.

8. Dantas FT, Martins SHL, Irie MS, Bastos GF, Souza SLS. Synthetic bone substitutes for implant dentistry- a literature review. INPerio 2016;1(1):97-103. 
9. Spin-Neto R, Stavropoulos A, Coletti FL, Faeda RS, Pereira LA, MarcantonioE Jr. Graft incorporation and implant osseointegration following the use of autologous and fresh-frozen allogeneic block bone grafts for lateral ridge augmentation. Clin Oral Implants Res. 2014 Feb;25(2):226-33. doi: 10.1111/clr.12107. Epub 2013 Jan 25.

10. Spin-Neto R, Stavropoulos A, Coletti FL, Pereira LA, Marcantonio E Jr, Wenzel A. Remodeling of cortical and corticocancellous fresh-frozen allogeneic block bone grafts - a radiographic and histomorphometric comparison to autologous bone grafts. Clin Oral Implants Res. 2015 Jul;26(7):747-52. doi: 10.1111/clr.12343. Epub 2014 Feb 21

11. Bojar W, Kucharska M, Ciach T, Koperski L, Jastrze Z, Szałwinski $M$. Bone regeneration potential of the new chitosan-based alloplastic biomaterial. J Biomater Appl. 2014 Mar;28(7):1060-8. doi: 10.1177/0885328213493682. Epub 2013 Jun 24.

12. Carvalho PS, Carvalho MC, Ponzoni D. Reconstruction of alveolar bone defect with autogenous bone particles and osseointegrated implants: Histologic analysis and 10 years monitoring. Ann Maxillofac Surg. 2015 Jan-Jun;5(1):135-9. doi: 10.4103/22310746.161145

13. Miron RJ, Sculean A, Shuang Y, Bosshardt DD, Gruber R, Buser D, et al. Osteoinductive potential of a novel biphasic calcium phosphate bone graft in comparison with autographs, xenografts, and DFDBA. Clin Oral Implants Res. 2016 Jun;27(6):668-75. doi: 10.1111/clr.12647. Epub 2015 Jul 30.
14. Spin-Neto R, Landazuri Del Barrio RA, Pereira LA, Marcantonio RA, Marcantonio E, et al. Clinical similarities and histological diversity comparing fresh frozen onlay bone blocks allografts and autografts in humanmaxillary reconstruction. Clin Implant Dent Relat Res. 2013 Aug;15(4):490-7. doi: 10.1111/j.17088208.2011.00382.x. Epub 2011 Aug 11.

15. Acocella A, Bertolai R, Colafranceschi M, Sacco R. Clinical, histological and histomorphometric evaluation of the healing of mandibular ramus bone block grafts for alveolar ridge augmentation before implant placement. J Craniomaxillofac Surg. 2010 Apr;38(3):222-30. doi: 10.1016/j.jcms.2009.07.004. Epub 2009 Aug 3.

16. Mendes EA. Utilização de enxertos homogenos: Provenientes de banco de ossos, [tese]. Bahia: Funorte; 2009 apud Abbot LC, Schottstaedt ER, Saunders JBCM, Bost FC. The Evaluation of Cortical And Cancellous Bone As Grafting Material; a clinical and experimental study. J Bone Joint Surg Am. 1947 Apr;29(2):381-414.

17. Aslan E, Gultekin A, Karabuda C, Mortellaro C, Olgac V, Mijiritsky E. Clinical, Histological, and Histomorphometric Evaluation of Demineralized Freeze-Dried Cortical Block Allografts for Alveolar Ridge Augmentation. J Craniofac Surg. 2016 Jul;27(5):1181-6. doi: $10.1097 /$ SCS. 0000000000002548 .

\section{Michelle Bianchi de Moraes} (Corresponding address)

Av. Eng. Francisco José Longo, $n^{\circ} 777$ Jardim São Dimas

12245-000 - São José dos Campos, SP

Date submitted: 2017 Feb 02

Telefone: (12) 3947-9000 